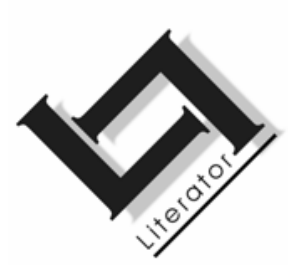

\title{
Wie skryf wat vir wie? \\ 'n Outeursprofiel van die Afrikaanse kinder- en jeugprosa (fiksie) 1990-2001
}

\author{
Maritha Snyman \\ Departement Inligtingkunde \\ Universiteit van Pretoria \\ PRETORIA \\ E-pos: mesnyman@postino.up.ac.za
}

\begin{abstract}
Who writes what for whom? An authors' profile of Afrikaans children's and youth prose (fiction) 1990-2001

In this article a profile of authors in the production category Afrikaans children's and youth prose (fiction) for the period 1990-2001 is compiled according to selected categories. The profile attempts to determine whether trends can be identified and statements and opinions of researchers with regard to this production category be corroborated by inferences drawn from this profile. Among others, the article addresses issues such as the age and gender of authors, the relation between authors and publishers and the influences of prices and awards on the publishing and writing patterns in this production category. It was found that a statistical analysis of authors involved in this publication category corroborated perceptions and findings of researchers in the field and can also identify and predict trends and problems.
\end{abstract}

\section{Opsomming}

Wie skryf wat vir wie ? 'n Outeursprofiel van die Afrikaanse kinder- en jeugprosa (fiksie) 1990-2001

In hierdie artikel word 'n outeursprofiel van die produksiekategorie Afrikaanse kinder- en jeugprosa (fiksie) vir die periode 1990-2001 saamgestel volgens vooraf bepaalde kategorieë. Die outeursprofiel poog om vas te stel of bepaalde tendense in hierdie produksiekategorie geïdentifiseer kan word en of stellings en standpunte van navorsers ooreenkom met afleidings wat op grond van hierdie outeursprofiel gemaak kan word. Die artikel behandel, onder andere, sake soos die ouderdom en geslag van outeurs, die verhouding 
tussen outeurs en uitgewers en die invloed van pryse en toekennings op die uitgee en skryf van boeke in hierdie produksiekategorie. Ten slotte word bevind dat 'n statistiese analise van die outeurs wat tussen 1990 en 2001 betrokke was in hierdie produksiekategorie, in die meeste gevalle die waarnemings en bevindings van navorsers ondersteun en tendense en probleme kan uitwys.

\section{Die rol van produksiestatisiek in die Afrikaanse jeugliteratuursisteem}

Betroubare produksiestatistiek van 'n spesifieke produksiekategorie kan, soos wat dit gebruik word in boekstudies, 'n bydrae lewer om besluite oor die uitgee van boeke gefundeerd te neem en risiko's in 'n mate te beperk. Dit kan ook binne die groter literatuursisteem 'n empiriese basis verskaf om gevolgtrekkings oor die stand van 'n spesifieke produksiekategorie te maak en as maatstaf gebruik te word om menings en waarnemings oor 'n bepaalde produksiekategorie te evalueer.

Snyman (2001; vgl. ook Wybenga \& Snyman, 2004) stel 'n publikasieprofiel van die jeugreeksboek in Afrikaans op en gebruik dit om waarnemings oor die ontwikkeling van dié subproduksiekategorie binne die Afrikaanse jeugliteratuursisteem te maak. Snyman en Venter (2004) verskaf later 'n oorkoepelende statistiese blik op die produksietendense van die produksiekategorie, die Afrikaanse kinder- en jeugprosa (fiksie). Hulle gebruik data wat beskikbaar is in die Produksietendensedatabasis (PTD) $\mathbf{1}$, gevestig in die program Uitgewerswese aan die Universiteit van Pretoria, en doen 'n verkennende ontleding van die produksietendense in hierdie produksiekategorie vir die periode 1990-2001.

Die afleidings wat volg uit laasgenoemde produksieprofiel bevestig empiriese waarnemings en uitsprake van onder andere Snyman (1994), Breytenbach (1999), Jacobs (2002) en Samuels (2004,) dat die Afrikaanse kinder- en jeugboekbedryf onder druk verkeer en wys moontlike probleme en leemtes in die uitgee van Afrikaanse kinderen jeugprosa uit. Dié ontleding ondersteun ook statisties die waarnemings van Fairer-Wessels en Van der Walt (1999:98) dat die

1 Die PTD kan beskryf word as 'n prototipe databasis van die aantal titels wat per jaar deur Suid-Afrikaanse uitgewerye uitgegee word en waaruit bepaalde produksietendense afgelei kan word. Die PTD word jaarliks opgedateer en voortdurend verder afgerond, afhangende van die beskikbare infrastruktuur. Die ontstaan en ontwikkeling van die PTD word beskryf deur Galloway (2002:212215). 
groot rol wat die voorskryfmark in die vorming van uitgewersfilosofie ten opsigte van uitgee van Afrikaanse kinder- en jeugliteratuur gespeel het - 'n "steriele letterkunde wat niemand wou lees nie" tot gevolg gehad het. Hierdie stelling word deur Wessels wat onlangs die leisels van NB-uitgewers oorgeneem het, in 'n koerantonderhoud bevestig:

As die skoolboekmark ly, ly 'n groot deel van die uitgewerybedryf ... uitgewerye werk (tans) daaraan dat ander dele van die bedryf, soos die algemene en akademiese uitgewerye in eie reg winsgewend ... is (Smith, 2004:9).

In haar polisistemiese benadering tot die bevordering van kleuter-, kinder- en jeugliteratuur verwys Van der Westhuizen (1999:130) ook na die "produksiekant" van die jeugliteratuur, waaronder sy skrywers, vertalers, illustreerders, manuskripkeurders, uitgewers en ander verwante rolspelers tel. Sy sonder die jeugboekskrywer, as "skepper van die produk", uit en beweer dat die motivering vir die skryf van kinder- en jeugboekouteurs in 'n hoë mate van die uitgewer afhang, "... want indien die uitgewer besonder positief is oor jeugboeke, sal hy/sy dit ook intensief bemark deur allerlei kanale".

Daar is dus besluit om ook 'n outeursprofiel van die produksiekategorie Afrikaanse kinder- en jeugprosa (fiksie) vir die tydperk 1990-2001 op te stel en uit te vind in hoe 'n mate uitsprake en menings van navorsers oor die Afrikaanse kinder- en jeugliteratuur deur statistiese ontledings ondersteun word en of afleidings uit 'n outeursprofiel waarde sou inhou vir uitgewerye en ander rolspelers in die "Afrikaanse jeugliteratuur as polisisteem" (Van der Westhuizen, 1999:130).

\section{Outeursprofiel gedefinieer}

'n Outeursprofiel kan gedefinieer word as 'n lys outeurs wat in 'n bepaalde produksiekategorie boeke skryf en wat ten minste die volgende inligting oor die outeurs bevat:

- die outeur se volle naam en van;

- geboortedatum van die outeur;

- gepubliseerde titels wat deur die outeur geskryf is;

- die datums van gepubliseerde titels; en

- die verskillende subproduksiekategorieë waarbinne die titels val. 
Die outeursprofiel kan verder aangevul word deur kategorieë by te voeg volgens die vereistes van 'n bepaalde toepassing.

In hierdie artikel word die aanname gemaak dat dit deur middel van 'n outeursprofiel moontlik behoort te wees om binne die konteks van 'n bepaalde produksiekategorie, die volgende te kan doen:

- leemtes ten opsigte van die aanbod van outeurs uit te wys;

- kenmerke van outeurs te identifiseer;

- uit te vind hoe die verspreiding van outeurs en die aktiewe uitgewerye in die produksiekategorie daar uitsien;

- te bepaal waardeur outeurs gemotiveer word al dan nie; en

- tendense binne die produksiekategorie te bepaal.

Dit spreek vanself dat die funksies van die outeursprofiel kan uitbrei indien die kategorieë wat in die outeursprofiel betrek word, vermeerder.

\section{Werkswyse}

Omdat die outeursprofiel van die produksiekategorie Afrikaanse kinder- en jeugprosa (fiksie) vir die periode 1990-2001 'n verdere verfyning en uitbreiding is van die produksieprofiel ${ }^{2}$ van die Afrikaanse kinder- en jeugprosa (fiksie) vir die periode 1990-2001 wat deur Snyman en Venter (2004) opgestel en beskryf is, word die werkswyse wat gevolg is om dié produksieprofiel op te stel, kortliks beskryf.

Venter (2004) onttrek eers data oor Afrikaanse fiksie (Deweyklasnommer "893.36*") uit die Suid-Afrikaanse Nasionale Bibliografie (SANB)3; daarna titels van kinder- en jeugliteratuur (aangedui met "J") en daarna inskrywings wat as prosa geklassifiseer kan word. Die titels wat op hierdie manier geïdentifiseer is, word daarna, sover moontlik, geverifieer deur dit te vergelyk met die fisiese boeke; publikasielyste wat deur uitgewerye beskikbaar gestel is; lyste van

2 'n Produksieprofiel verwys na alle titels wat binne 'n gegewe tyd in 'n bepaalde produksiekategorie uitgegee is (Venter \& Galloway 2002).

3 Die SANB word deur die National Library of South Africa (NLSA) saamgestel en stel 'n lys van bibliografiese inskrywings van titels saam wat plaaslik uitgegee is en waarvan pligeksemplare deur uitgewerye by die NLSA ingelewer is - soos wat die Wet op Pliglewering (Suid-Afrika 1997) vereis. 
nuwe Afrikaanse titels wat opgestel is deur die Nasionale Afrikaanse Letterkundemuseum en Navorsingsentrum (NALN) en gepubliseer is in Tydskrif vir Letterkunde; inligting vervat in die Afrikaanse jeugliteratuurgeskiedenis Van Patrys-hulle tot Hanna Hoekom. 'n Gids tot die Afrikaanse kinder- en jeugboek (Wybenga \& Snyman, 2004); en vakkennis van kundiges, wat die outeur, bibliotekarisse en uitgewers insluit.

Hierdie data, wat as 'n redelike korrekte weergawe van die produksie van Afrikaanse kinder- en jeugboeke tussen 1990 tot 2001 beskou kan word, is die basis waaruit die finale produksieprofiel van die Afrikaanse kinder- en jeugprosa (fiksie) vir die periode 1990-2001 saamgestel is. Dit verskaf inligting oor die uitgewerye betrokke by die uitgee van titels in die produksiekategorie, die titels en jaar van uitgawe, die outeurs, of dit 'n oorspronklike of vertaalde werk is en inligting oor subproduksiekategorieë.

Die titels wat versamel is om die produksieprofiel (soos hierbo beskryf) tot stand te bring, vorm die basis vir die outeursprofiel. Alle titels wat oorspronklik (eerste) in Afrikaans verskyn het, is vanuit die produksieprofiel onttrek. Hierdie titels is daarna gekategoriseer volgens die outeurs, hulle geboortedatums, die titels van die boeke geskryf deur die outeurs en jaar van uitgawe, die uitgewerye wat die titels uitgegee het en subproduksiekategorieë.

Die induktiewe proses waarmee die data van die outeursprofiel geanaliseer is, het grootliks ooreengekom met die proses van inhoudsanalise soos Berg (1998) dit beskryf. Soos wat die data gekategoriseer is, het bepaalde patrone na vore gekom. Vrae is na aanleiding van die data wat bekom is gestel en die data is met beskikbare eksterne inligting gekorreleer. Dit het daartoe aanleiding gegee dat die verhouding tussen geselekteerde kategorieë ondersoek is, bykomende inligting versamel is en kategorieë aangepas is. Hierdie proses sal in die res van dié artikel verder belig word wanneer die afleidings beskryf word.

Dit is noodsaaklik om daarop te wys dat hierdie artikel deskriptief is en daar nie gepoog sal word om die resultate van die analise te interpreteer of te kontekstualiseer nie. Slegs opvallende diskrepansies sal uitgewys en bevraagteken word en menings van akademici oor hierdie produksiekategorie sal geëvalueer word.

Die subjektiewe oordeel van die outeur en navorser word in die proses erken. Dit is juis agtergrondkennis van dié produksie- 
kategorie wat die navorser in staat gestel het om op induktiewe wyse patrone in die data te identifiseer, diskrepansies waar te neem en moontlike negatiewe of positiewe punte uit te wys.

Inligting wat uit die produksieprofiel verkry is, het in 'n groot mate bepaal hoe die analiseringsproses van die outeursprofiel verloop het. Die volgende afleidings uit die produksieprofiel (Snyman \& Venter, 2004), het 'n rol gespeel by die ontleding van die outeursprofiel en gehelp om gekontekstualiseerde afleidings te maak:

- Die totale aantal Afrikaanse kinder- en jeugprosatitels (fiksie) wat in die periode 1990-2001 verskyn het, is ongeveer 1475 . Die produksieprofel dui egter 'n beduidende daling van $71 \%$ oor 11 jaar aan.

- Die uitgewerye wat in hierdie tydperk betrokke is by die publikasie van Afrikaanse kinder- en jeugprosa (fiksie) word in drie kategorieë gegroepeer, naamlik:

- prominente uitgewerye 4 wat die volgende (in alfabetiese volgorde) insluit: Anansi, Daan Retief/Kennis Onbeperk, Human \& Rousseau, Jacklin Enterprises, Perskor/Kagiso, Tafelberg, J.P. van der Walt \& Seun/LAPA en J.L. van Schaik;

- nie-ware rolspelers 5 (in alfabetiese volgorde) wat uitgewers soos die volgende insluit: Benedic, Bok-boeke, CUM-boeke, De Jager-HAUM, Delos, Fantasi, Fundi, Garamond, Gecko, Hans Kirsten, Horne \& De Villiers, Jonathan Ball, Juta, Juventus, Klipbok, Leo Uitgewery, Lig in duisternis, Marius Lubbe, Maskew Miller Longman, Môrester Publikasies, Nasou, Orion, Oxford, Prisma, Pro Biblia, Publitoria, Queillerie, Random House, Rubicon, Struik, Uniboek, Varia, Via Afrika, Vivlia, Vlaeberg en Waterkant/Lux Verbi; en

- outeurs wat hulle eie boeke uitgee.

- Die profiel van prominente uitgewerye wat Afrikaanse kinder- en jeugprosa (fiksie) gedurende die periode 1990-2001 uitgee, ondergaan groot veranderinge in die tydperk. Daan Retief

4 Prominente uitgewerye kan beskou word as uitgewerye wat deurentyd, of vir die grootste gedeelte van die tydperk, 'n beduidende aantal Afrikaanse kinder- en jeugprosa uitgegee het (Snyman \& Venter, 2004).

5 Nie-ware rolspelers kan gedefinieer word as uitgewerye wat, vir 'n sekere tydperk, af en toe, of vir korter tydperke binne die periode 1990 tot 2001 enkele of meer titels uitgegee het (Snyman \& Venter, 2004). 
verdwyn van die toneel en Anansi gee sedert 1998 slegs twee Afrikaanse titels uit. Perskor, een van die produktiefste uitgewerye van oorspronklike Afrikaanse titels, word oorgeneem deur Kagiso en later deur Maskew Miller Longman wat nie meer Afrikaanse prosa uitgee nie. J.P. van der Walt \& Seun word oorgeneem deur LAPA, wat belofte vir groei inhou. Die twee grootste uitgewerye van Afrikaanse kinder- en jeugprosa, Human \& Rousseau en Tafelberg, se produksie neem drasties af.

- Oorspronklike Afrikaanse tekste maak slegs $34 \%$ van die totale produksie van Afrikaanse kinder- en jeugprosa (fiksie) uit. Die res is vertalings en/of ko-produksies.

- Die oorgrote meerderheid, naamlik $94 \%$ van vertaalde Afrikaanse kinder- en jeugprosa is gerig op die kleiner kind.

\section{4. 'n Outeursprofiel van die produksiekategorie Afrikaanse kinder- en jeugprosa (fiksie) vir die periode 1990-2001}

$\mathrm{Na}$ die samestelling en verifiëring van die databasis, is besluit om aanvanklik op die volgende ontledingskategorieë te fokus:

- die aantal outeurs wat oorspronklik in Afrikaans oor die tydperk gepubliseer het;

- die verhouding tussen manlike en vroulike outeurs;

- die verhouding tussen outeurs van die twee Afrikaanstalige groeperings;

- die ouderdomme van die betrokke outeurs tydens hierdie tydperk;

- die hoeveelheid titels wat betrokke outeurs in hierdie tydperk geproduseer het; en

- die subpublikasiekategorieë waarby die outeurs in hierdie tydperk betrokke is.

\subsection{Die aantal outeurs wat oorspronklike Afrikaanse kinder- en jeugprosa (fiksie) in die periode 1990-2001 publiseer}

Altesaam 191 outeurs $^{6}$ is betrokke by die skryf van Afrikaanse kinder- en jeugprosa (fiksie) in die tydperk 1990-2001. Die aantal van titels vootdurend plaasvind, maar bevat verreweg die meeste en belangrikste outeurs in hierdie produksiekategorieë. 
outeurs wat per jaar in hierdie tydperk publiseer, word in Figuur 1 hieronder aangetoon.

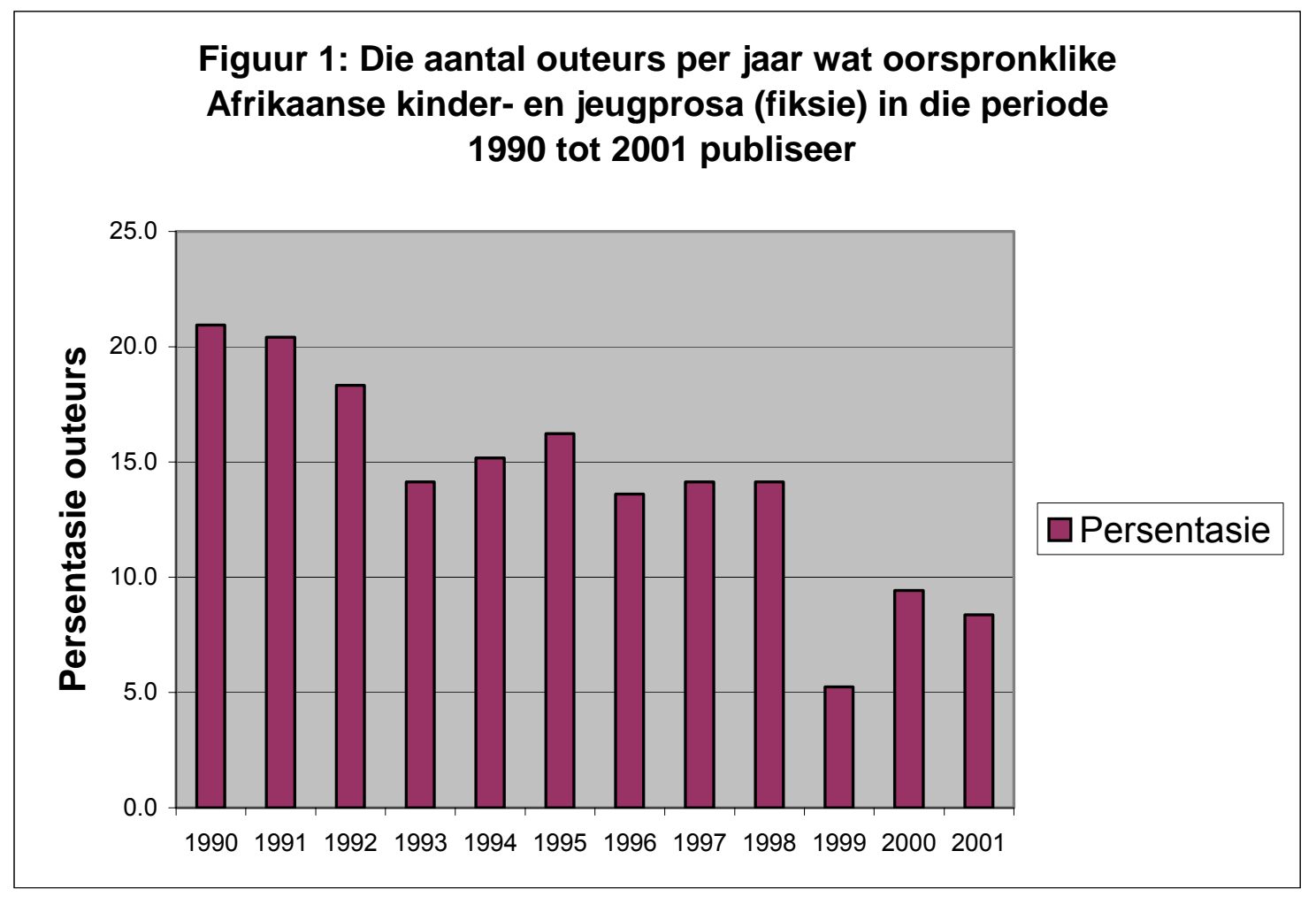

Die outeursprofiel volg die patroon van die produksieprofiel soos beskryf deur Snyman en Venter (2004) en vertoon 'n skerp afname van $15 \%$ tussen 1990 tot 1999 , hoofsaaklik as gevolg van politieke veranderinge, die ineenstorting van die voorskryfmark en die gevolglike skommelinge by uitgewerye wat Afrikaanse kinder- en jeugboeke publiseer. Die effense styging wat vanaf 2000 voorkom, is waarskynlik te danke aan die toetrede van LAPA en die feit dat die oorblywende uitgewerye van Afrikaanse kinder- en jeugboeke by die veranderde omstandighede begin aanpas het.

\subsection{Die verhouding tussen manlike en vroulike outeurs wat Afrikaanse kinder- en jeugprosa (fiksie) in die tydperk 1990-2001 publiseer}

Die statistiek toon aan dat $30 \%$ van die outeurs manlik en $70 \%$ vroulik is. Dit korreleer moontlik met die verwagting dat vroue tradisioneel die verantwoordelikheid van kinders se opvoeding dra en dat verskeie outeurs van Afrikaanse kinder- en jeugprosa al 
aangedui het dat hulle begin skryf het omdat daar nie genoeg leesstof vir hulle eie kinders beskikbaar is nie en hulle die stories neerskryf wat hulle altyd vir hulle kinders vertel het. Die afleiding kan ook gemaak word dat 'n noue betrokkenheid by kinders dikwels 'n rol speel in die besluit om kinder- en jeugliteratuur te skryf. Dit blyk, onder andere uit die feit dat heelwat van die outeurs wat vir kinders skryf, ook buite familieverband met kinders gemoeid is (Wybenga \& Snyman, 2004). Bekende outeurs soos Cor Dirks, Topsy Smit, Leon de Villiers, Karel Kielblock, Marietjie de Jong, Louise Prinsloo, Tienie Holloway, Barrie Hough en ander was of is byvoorbeeld betrokke by onderwys (Wybenga \& Snyman, 2004).

\subsection{Die ouderdomme van die outeurs wat Afrikaanse kinder- en jeugprosa (fiksie) in die tydperk 1990-2001 produseer}

Aangesien slegs 147 van die 191 outeurs se geboortedatums uit die SANB en in literatuurgeskiedenisse vasgestel kon word, is die statistiese afleidings op grond daarvan gemaak en word dit in Figuur 2 aangedui:

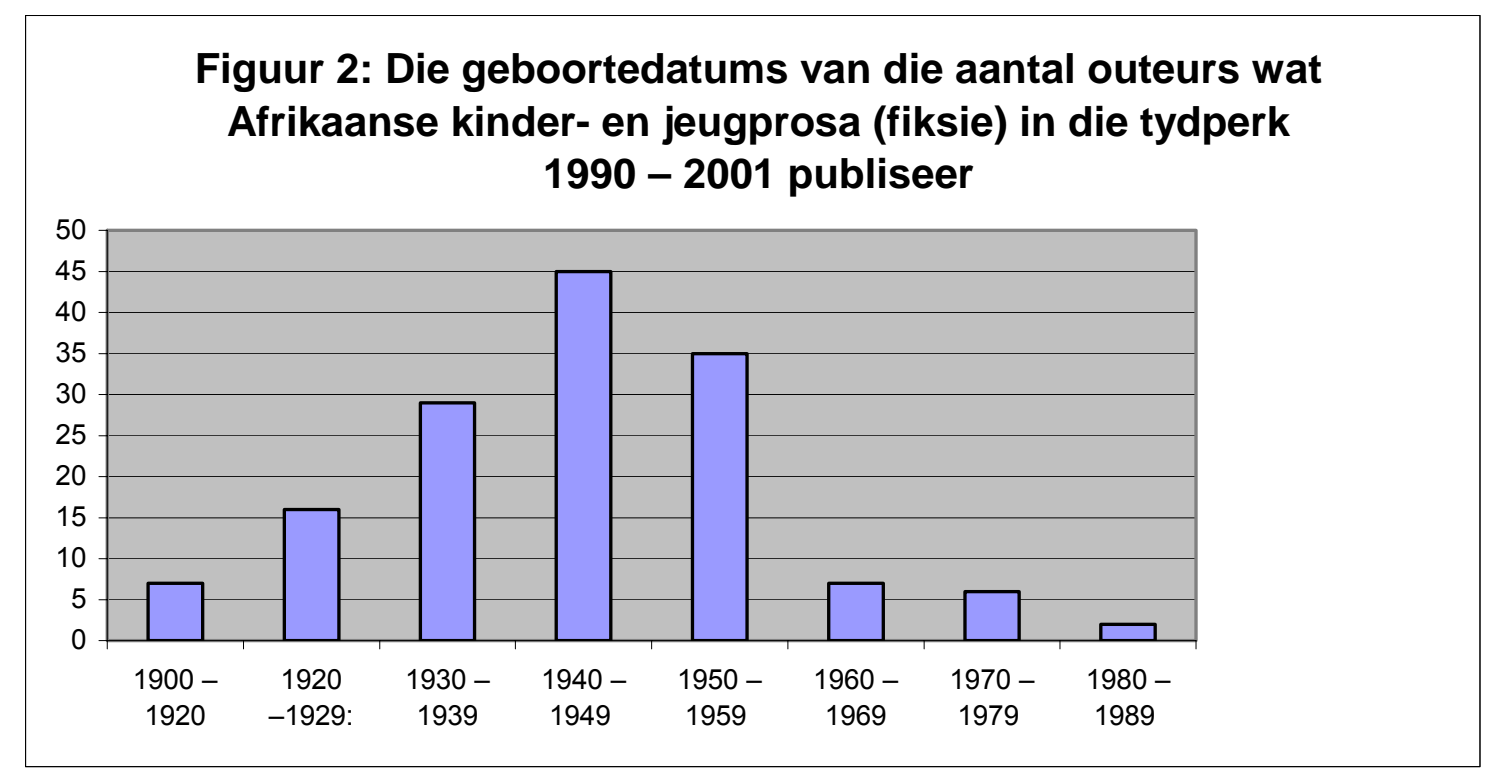

Sewe outeurs wat in die tydperk 1990-2001 publiseer, is by die publikasie van hulle boeke reeds om en by die 80 jaar oud. Onder hulle tel relatiewe onbekende outeurs soos C.R. de Wet (1917), Elizabeth Hoekstra (1908), Emily Pieterse (1917) en Le Roi Steenkamp (1917). Ander is meer bekend. Elizabeth van der Merwe (1916) verower op 77-jarige ouderdom die Tienie Holloway-medalje 
en die M.E.R.-prys vir haar Kaljander van die Karoo (1993)7. Cor Dirks (1911), die vader van die Uile-reeks, skryf op 79-jarige ouderdom die laaste Uile-boek, Die Uile vlieg weer (1990), terwyl Topsy Smit (1915) 67 jaar oud is toe hy sy laaste jeugboek, Nog net een keer (1991), skryf.

Outeurs wat tussen 1920 en 1929 gebore is, is in die tydperk 19902001 verantwoordelik vir $11,4 \%$ van die totale aanbod boeke. Bekendes onder hulle wat titels in hierdie tydperk publiseer, is onder andere Empie Maritz met Eiland in die wind (1990) en Windvlug (1995); Kas van den Berg wat twee jeugreeksboeke Skaduwee oor Overvaal (1996) en Die spesialiste op Overvaal (1996) skryf en Rena Schüler wat Vriende van eggo (1993), Ek sal moet leer dans, Shaleen (1996) en Die somervakansie wat te lank was (2000) skryf. Vir laasgenoemde is die Sanlamprys aan haar toegeken.

Die oorgrote meerderheid titels in die tydperk 1990-2001 is afkomstig van outeurs wat tussen 1930 en 1959 gebore is. Die gemiddelde ouderdom van die outeurs wat $87 \%$ van die totale aanbod oorspronklike Afrikaanse kinder- en jeugprosatitels in die periode 1990-2001 publiseer, is ongeveer 60 jaar.

Die feit dat outeurs in hierdie tydperk van hulle lewe die meeste en sommige van die beste en gewildste boeke (soos aangedui deur pryse en herdrukke) publiseer, kan waarskynlik aan een of meer van die volgende faktore toegeskryf word:

- Hulle is ervare en dus vaardige skrywers. In baie gevalle skryf sommige van hierdie outeurs gemaklik binne een of meer van die subpublikasiekategorieë van die produksiekategorie Afrikaanse kinder- en jeugprosa. Martie Preller is 'n goeie voorbeeld.

- Hulle het meer tyd tot hulle beskikking, omdat hulle waarskynlik afgetree het of nie meer 'n gesin het om te versorg nie.

Hoewel slegs sewe van die 147 outeurs wat in die outeursprofiellys opgeneem is in hulle veertigerjare is, is twee van hulle baie produktief en prominent. Francois Bloemhof publiseer 12 titels in hierdie periode, waarvan vier bekronings verwerf en Leon de Villiers vyf, waarvan twee bekroon word.

Vanaf 1995 verskyn 'n hele paar outeurs wat in hulle twintigerjare is op die toneel. Louise van Niekerk betrek in die skryf van die

$7 \quad$ Sy wen die prys vir 'n heruitgawe van die boek. 
Rëenboogrant- en Monstermaan-reekse vanaf 1995/1996 jong en onbekende outeurs, soos Hannes Smit en Ansonet Kruger, wat onder haar toesig skryf. Die ewe jong Martin Labuscagne skryf ook vir Perskor die Projek X-reeks. In 2001 tree Jaco Jacobs met Troetelgedrog en Duskant die doodlyn en Carina Diederichs-Hugo met Moord.net toe tot die Afrikaanse kinder- en jeugprosatoneel. Albei is in hulle vroeë twintigerjare en word aktiewe outeurs van Afrikaanse kinder- en jeugprosa in die jare na 2001. Die toetrede van jeugdige outeurs tot hierdie produksiekategorie, wat in 1995 begin met die Perskor-inisiatief van die uitgewers Cecilia Brits en Veronica Language om Arikaanse jeugreeksboeke te laat herleef (Snyman, 2001), verkry momentum en lei tot 'n nuwe tendens in die Afrikaanse kinder- en jeugprosa. Hierdie tendens om jonger outeurs te betrek, word verder versterk as die agtienjarige Jackie Nagtegaal in 2002 die M.E.R.-prys vir haar boek Daar's vis in die punch wen. Laasgenoemde drie jong outeurs ontvang tans heelwat mediadekking. Miemie du Plessis van LAPA gebruik Jacobs en Diederichs-Hugo met groot sukses vir die bemarking van boeke tydens skoolbesoeke. Diederichs-Hugo is in 2003 deur Human \& Rousseau as jeugboekuitgewer aangestel. Diederichs-Hugo maak ook van bemarkingsaksies by skole gebruik. Ook ouer outeurs is mettertyd deur albei uitgewers by hulle bemarkingsaksies betrek. Jacobs is ook by die groter Afrikaanse jeugliteratuursisteem betrek, omdat hy gereeld as resensent vir jeugboeke optree en later aangestel is as redakteur van Jip (Volksblad).

Die klem op jeugdige outeurs word verder weerspieël in drie ander publikasies wat in die periode 1990-2001 verskyn. Kwela-uitgewers gebruik tieners se werk om twee verhaalbundels vir tieners saam te stel: $E k$, 'n lewende pyl (1998) en Op met die af roltrap (2000) saamgestel deur onderskeidelik Hans Bodenstein en Linda Rode. Fantasi publiseer vir laerskoolkinders die Gruwelike, grieselrige, grilboek (2001), saamgestel deur Maritha Snyman uit kortverhale geskryf deur hoërskoolkinders.

Die fokus op jonger outeurs en die ontginning van die outeurs se persona as deel van die bemarking van boeke, is waarskynlik een van die uitvloeisels van die verskuiwing in uitgeweryfilosofie by uitgewerye van Afrikaanse kinder- en jeugprosa. Die fokus is nie meer net gerig op die voorskryfmark nie, maar ook op die ontginning en verbreding van die algemene mark. Dit lyk asof uitgewers toenemend besef dat teikenlesers op verskillende vlakke met boeke moet kan identifiseer om daarvan te hou (Ghesquiere, 1997; Snyman, 1999; Verwey, 1999) en dit gevolglik te koop. Van der 
Westhuizen (1999:136) betoog ten gunste van 'n meer lesergesentreerde benadering by die uitgee van kinder- en jeugboeke wanneer sy sê dat "dié lesers vir wie (jeugliteratuur) in die eerste plek bedoel is" en wat "iets van die teks moet oorhou ...", deur uitgewers erken moet word. Dit is juis die bewuswording om die kind as eindgebruiker van kinder- en jeugboeke te erken, wat daartoe lei dat kinder- en jeugboekuitgewers nou poog om boeke uit te gee wat deur teikenlesers as aanvaarbaar ervaar sal word. Hierdie uitgangspunt is waarskynlik waarop die aanname gegrond is dat jonger mense beter vir kinders kan skryf en dat kinders beter met hulle sal kan identifiseer. Daarom word gesoek na jong en bemarkbare outeurs. Vandaar kom ook die praktyk om van kinders gebruik te maak by die keuring van manuskripte. Trouens, dié tendens word ook in die breër jeugliteratuursisteem aangetref. Koerante gebruik toenemend kinderkeurders om jeugliteratuur te resenseer en jeugboekresensente verwys na die mening van kinderlesers in hulle resensies.

\subsection{Die verhouding tussen outeurs van verskillende Afrikaans- talige groeperings}

Omdat dit 'n gegewe is dat die Afrikaanstalige gemeenskap in SuidAfrika tradisioneel verdeel is in 'n wit en bruin groep, is ondersoek ingestel in watter mate hierdie historiese en sosiale verdeling in die Afrikaanse kinder- en jeugprosa verteenwoordig word.

Slegs een outeur uit die bruin Afrikaanse gemeenskap wat in die tydperk 1990-2001 'n Afrikaanse kinder- en/of jeugboek geskryf het, kon geïdentifiseer word. Hoewel Petra Sassen as wit Afrikaanstalige outeur haar Plek van die swart eende (1994) binne die leefwêreld van die bruin kind situeer, is dit slegs Zulfah Otto-Sallies se Diekie van die Bo-Kaap (1997) wat die Maleise tiener- en kultuuragtergrond vanuit die perspektief van 'n outeur binne die betrokke gemeenskap belig.

Hierdie onhoudbare toedrag van sake sal reggestel moet word indien uitgewerye die groter Afrikaanstalige gemeenskap in die skep en verbruik van Afrikaanse kinder- en jeugboeke wil betrek.

\subsection{Die hoeveelheid titels wat individuele outeurs van Afrikaanse kinder- en jeugprosa (fiksie) in die tydperk 1990-2001 produseer}

In Figuur 3 word die hoeveelheid titels wat individuele outeurs in die periode 1990-2001 publiseer, aangedui. 


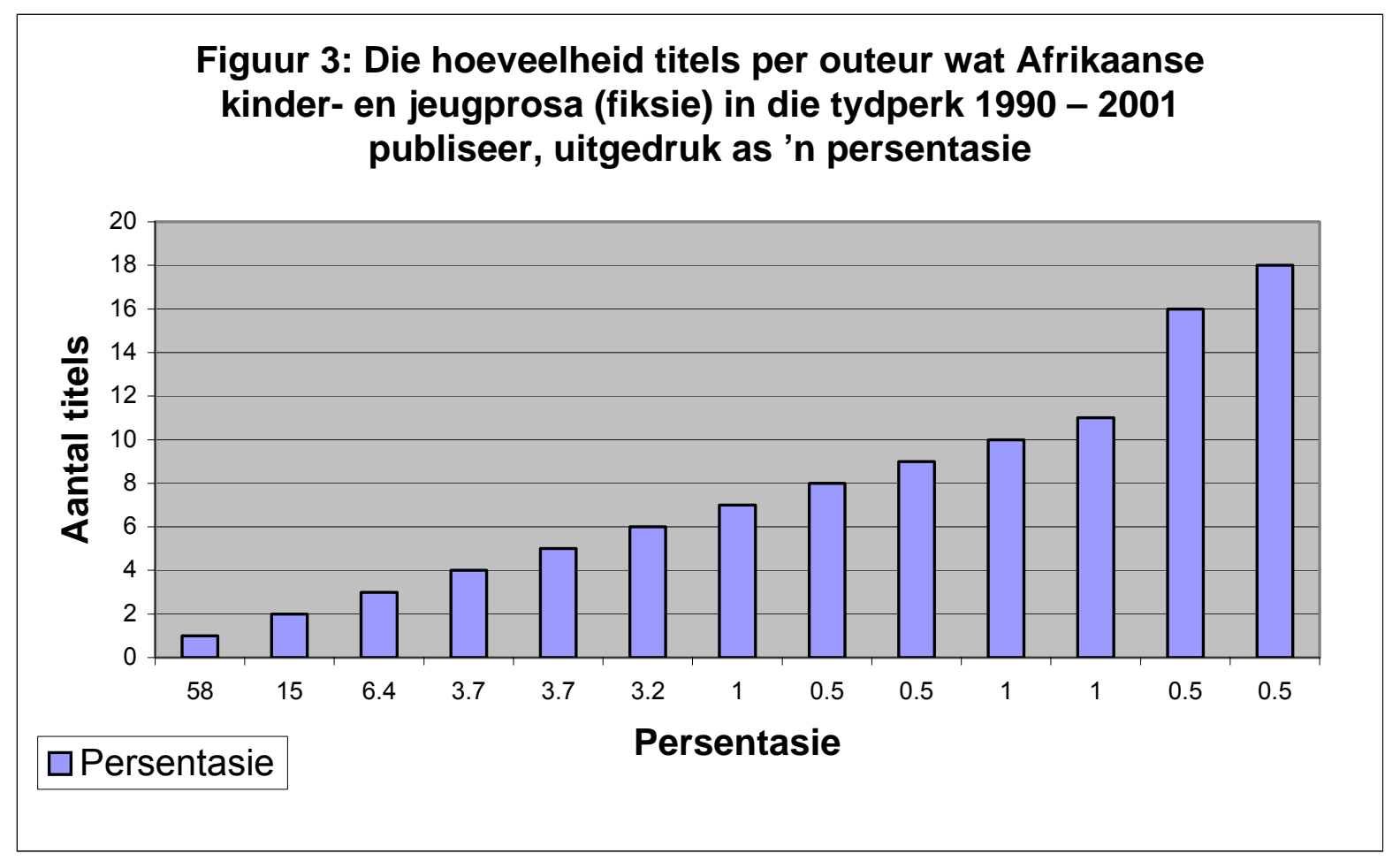

Die outeurs wat die meeste boeke in hierdie tydperk skryf, is die bekende kinder- en jeugboekouteur, Martie Preller. Kort op haar hakke is die minder bekende, maar baie produktiewe Louise van Niekerk, wat ook onder die pseudoniem Louis van Niekerk vanaf 1995 tot 2000 gemoeid is met die skryf van Perskor se Reënboogrant- en Monstermaan-reekse. Die bekende kinder- en jeugboekouteurs, Francois Bloemhof en Janie Oosthuysen, is in die derde plek en word gevolg deur outeurs soos Maretha Maartens, Louise Prinsloo, Maritha Snyman en Heila Fourie (laasgenoemde albei onder andere betrokke by die Perskor-reekse).

Meer as die helfte van die outeurs wat Afrikaanse kinder- en jeugprosa in dié periode skryf, publiseer slegs een titel. Omdat dit 'n tydrowende en duur proses vir 'n uitgewery is om 'n outeur te begelei ten einde ' $n$ aanvaarbare manuskrip in 'n persklaar boek te omskep, het die verskynsel dat $58 \%$ outeurs oor die tydperk tussen 1990-2001 net een titel geproduseer het, die navorser gemotiveer om te probeer vasstel wat die rede daarvoor is. Deur die data in meer diepte te bestudeer en in gesprekke met rolspelers in die bedryf te tree, is die volgende faktore as moontlike redes geïdentifiseer:

- Sommige van die outeurs $(4,8 \%)$ was produktiewe skrywers in die verlede, maar is oorlede. Hulle is onder andere Eleanor Baker, Cor Dirks, Cas van den Berg en Topsy Smit. 
- Sommige van die outeurs $(13,5 \%)$ skryf nie meer nie omdat hulle te oud en/of siek is.

- Om ander redes hou 3,8\% van outeurs op skryf. Twee van hulle neem 'n kognitiewe besluit om eerder liefdesverhale te skryf omdat dit meer winsgewend is, maar verkies dat hulle name nie genoem word nie.

- Van die outeurs wat vir Christelike uitgewerye skryf $(6,7 \%)$, publiseer net eenmalig in die publikasiekategorie.

- Sommige van die outeurs is steeds in die bedryf $(7,7 \%)$, maar publiseer weens verskillende redes net een boek in die tydperk. Johan van Lill skryf byvoorbeeld na sy eerste jeugroman, Die agtervolger (1998), tans leesreekse. Carina Diederichs-Hugo en Jaco Jacobs debuteer aan die einde van die tydperk, maar publiseer nog steeds. Verna Vels en Helene de Kock het nog nie een hulle uittrede aangekondig nie en sommige van die outeurs in hierdie kategorie is tans besig met manuskripte vir jeugboeke.

- 'n Persentasie $(3,8 \%)$ is outeurs van ander publikasiekategorieë, wat elkeen (tot dusver) net een kinder- en/of jeugboek die lig laat sien het. Hulle sluit onder andere die volgende outeurs in: Madeleine van Biljon (vertaler en joernalis) ${ }^{8}$ en Daleen Matthee (romansier) wat onderskeidelik die kleuterboeke Eduard kuier by Ouma (1992) en Die twaalfuur stokkie (1992) publiseer, asook Riana Scheepers (outeur van volwasseneprosa) wat Blinde sambok (2001) en Elize Parker (outeur van liefdesverhale en joernalis) wat Moenie vir Ma sê nie (2001) skryf. Parker stel nog drie tienerromans met kontensieuse temas in die vooruitsig (Nieuwoudt, 2001).

- Die redes waarom $20,4 \%$ van hierdie outeurs nie meer as een boek gepubliseer het nie, is onbekend en verdien verdere ondersoek. Hierdie kategorie sluit onder andere outeurs in wat relatiewe sukses behaal het: onder andere, Johann de Waal met !Sit Oom Paul, (1995), Elsa Hamersma met Die teken van crux (1998) en Arnold Vermaak met Buys (1999).

- Verreweg die grootste aantal outeurs, $42,7 \%$, wat slegs een boek gepubliseer het, se boeke val egter tans tematies en stylgewys buite die aanvraag van die hedendaagse teikenleser. Dit is opvallend dat heelwat outeurs in hierdie kategorie net een titel by

8 Madeleine van Biljon se Eduard kuier by ouma (1992) word hier as kinderboek gekategoriseer. 
Daan Retief/Kennis Onbeperk en/of J.P. van der Walt \& Seun publiseer - albei uitgewerye wat die persepsie gehad het dat hulle "populêr" uitgee. By J.P. van der Walt \& Seun, wat vanaf 2000 deur LAPA oorgeneem is, word Miemie du Plessis spesifiek as uitgewer van jeugboeke aangestel. Hier verskuif die uitgeefilosofie ten opsigte van wat as verkoopbare kinder- en/of jeugboeke beskou word gevolglik in so 'n mate dat die grootste aantal outeurs wat vir J.P. van der Walt \& Seun kinder- en jeugboeke in die periode voor 1999 publiseer, se werk nie meer as geskik geoordeel word nie. Hierdie verskuiwing kan, soos reeds gemeld is, aan die groter bewustheid by uitgewers oor die behoeftes van teikenlesers toegeskryf word en veroorsaak by ander uitgewerye dieselfde verskuiwing ten opsigte van die keuse van outeurs.

\subsection{Die subpublikasiekategorieë van Afrikaanse kinder- en jeugprosa (fiksie) waarby outeurs in die tydperk 1990- 2001 betrokke is}

In die produksieprofiel (Snyman \& Venter, 2004) is die volgende subpublikasiekategorieë onderskei: bababoeke, prenteboeke of kinderboeke $\left(10\right.$ jaar $\left.^{+}\right)$. Bababoeke is gedefinieer as boeke wat geskik is vir kleuters onder twee jaar oud en het plasboeke en kartonboeke ingesluit; prenteboeke is gedefineer as geïllustreerde boeke vir kleuters en jonger kinders; terwyl kinderboeke $\left(10\right.$ jaar $\left.^{+}\right)$ verwys het na narratiewe tekste vir ouer kinders. Hierdie subpublikasiekategorieë is egter in die outeursprofiel wat hier beskryf word, verander.

Aangesien bababoeke uitsluitlik ko-produksies is en gevolglik nie 'n geldige subpublikasiekategorie is vir 'n outeursprofiel waarin daar slegs met oorspronklike Afrikaanse tekste gewerk word nie, is besluit om drie ander subpublikasiekategorieë hier te gebruik, naamlik kleuterboeke, kinder-/jeugboeke en aktiwiteitsboeke. Kleuterboeke verwys na prenteboeke waar die visuele en verbale teks dieselfde gewig dra. Die besluit om naas kleuterboeke slegs kinderboek/jeugboek as kategorieë te selekteer, spruit voort uit die redenasie dat die vaardighede om 'n verhalende teks te skryf waarin die visuele hoogstens bykomend of weglaatbaar is, verskil van die vaardighede wat vereis word om 'n kleuterboek te skryf waarin die verbale teks in simbiose met die visuele teks funksioneer. Speletjies en/of grapboeke pas nie in een van bogenoemde twee kategorieë nie, omdat die klem nie op die narratiewe óf die visuele teks val nie, maar op die vermoë van die teks om die leser aktief by die lees- 
proses te betrek. Daarom word hierdie subpublikasiekategorie, aktiwiteitsboeke genoem.

In Figuur 5 word die verspreiding van outeurs volgens subpublikasiekategorie aangedui.

Figuur 5: Die verspreiding van outeurs van Afrikaanse kinderen jeugboekprosa tussen 1990 - 2001 volgens subpublikasiekategorieë

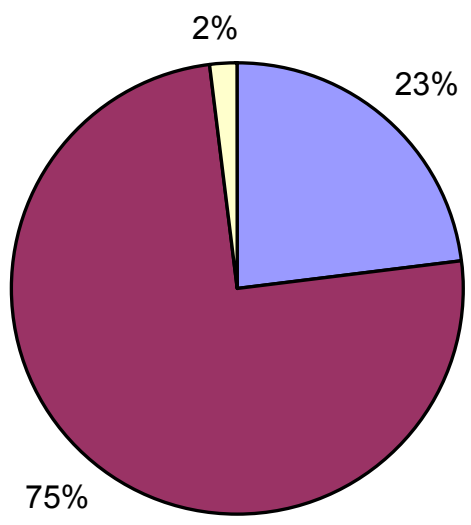

Anders as in die geval van die produksieprofiel wat aandui dat $94 \%$ van vertaalde Afrikaanse tekste op die kleiner kind gerig is, dui die outeursprofiel aan dat kleuterboeke slegs $22,2 \%$ van die totale aanbod oorspronklike Afrikaanse kinder- en jeugprosa uitmaak. Hierdie teenstrydigheid kan waarskynlik toegeskryf word aan die hoë koste van volkleurkleuterboeke. Dit is meer winsgewend vir uitgewerye om kleuterboeke as ko-produksies uit te gee, as wat dit is om oorspronklike kleuterboeke te skep.

Die subpublikasiekategorie aktiwiteitsboeke is klein, maar relatief nuut in die Afrikaanse kinder- en jeugboekbedryf. Hierdie publikasiekategorie is in die tagtigerjare feitlik volledig verteenwoordig deur Pieter W. Grobbelaar se 'n Bietjie baie bogtery (1980) wat hy in 1988 opvolg met Liewe lawwe lollery waarin grappe, getalspeletjies, raaisels, leesspeletjies, ensovoorts die leser op 'n kognitief-stimulerende wyse besighou. Die toename in aktiwiteitsboeke dui waarskynlik op 'n poging om ook die belangstelling van die kind vir boeke in die algemene mark te ontgin en lees te bevorder.

'n Verdere ontleding van die data dui aan dat sommige outeurs in die publikasiekategorie Afrikaanse kinder- en jeugboeke in ten minste twee - en in sommige gevalle in al drie die subpublikasiekategorieë - boeke skryf. Martie Preller is waarskynlik hier die 
belangrikste voorbeeld. Sy wen byvoorbeeld die Sanlamprys vir haar jeugboek In die tyd van die Esob (1996) en vir Die Balkieboek (2000), 'n kinderboek, die Alba Bouwer-prys. Met haar kleuterboeke Babalela (2000) en Lisa het 'n plan (2001) verower sy die Tienie Holloway-medalje. Daarbenewens wen sy met die derde van haar kies-jou-eie-avontuur-boeke, Jy en Toetenkat (1994), 'n ATKV-toekenning. Ook Maretha Maartens publiseer in al drie subpublikasiekategorieë. Sy wen die Sanlam-prys vir die jeugboeke Plek van die dolfyne (1990) en Spinnekopsomer (1992); sy skryf Die keerpunt (1991), 'n kies-jou-storie-boek en Die nagkat (1998), 'n kleuterboek. Ander voorbeelde van outeurs wat in meer as een subpublikasiekategorie publiseer, is onder andere Leon de Villiers, Mari Grobler, Elsabe Steenberg en Marita van der Vyver.

\subsection{Die verspreiding van outeurs volgens uitgewerye}

Om te bepaal hoe die outeurs versprei is tussen uitgewerye wat vanaf 1990-2001 Afrikaanse kinder- en jeugprosa uitgee, is die indeling van uitgewerye soos wat dit in die produksieprofiel (Snyman \& Venter, 2004) gebruik is, ook hier van toepassing gemaak. Die prominente uitgewerye ${ }^{9}$ van Afrikaanse jeugprosa is as afsonderlike kategorieë geselekteer. Nie-ware rolspelers is as 'n enkelkategorie aangedui en so ook boeke wat self deur outeurs uitgegee is.

Figuur 6 toon die verspreidingsprofiel van outeurs van Afrikaanse kinder- en jeugprosa (fiksie) vir die periode 1990-2001 aan.

Anansi en Jacklin Enterprises word nie in hierdie verspreidingsvoorstelling betrek nie, omdat hulle byna uitsluitlik vertaalde werke en heruitgawes uitgee en dus geen nuwe oorspronklike Afrikaanse titels nie. Ook uitgewerye soos Human \& Rousseau en sommige van die nie-ware rolspelers se aandeel is hier veel kleiner as gevolg van dieselfde rede. Boeke wat self deur die outeurs uitgegee word, is weglaatbaar min.

Dit blyk dat as gesamentlike groepering, die nie-ware rolspelers die grootste aantal outeurs verteenwoordig, naamlik 24,4\%. Dié persentasie kan waarskynlik toegeskryf word aan die aandeel van Christelike uitgewers soos Waterkant, CUM, Lux Verbi en ander. J.P. van der Walt \& Seun word deur $21,9 \%$ van die outeurs ondersteun; daarna volg Tafelberg met $20,6 \%$ en Human \& Rousseau met $14,3 \%$. 
Figuur 6: Die verspreiding van outeurs van Afrikaanse kinderen jeugprosa tussen uitgewerye vir die periode 1990 tot 2001

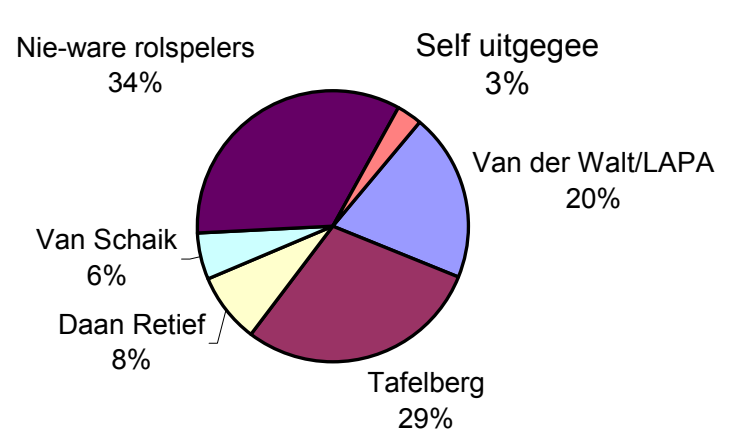

Volgens die verspreiding van outeurs tussen uitgewerye, lyk dit of daar 'n skeiding tussen die Nasboek-uitgewerye'10 (Human \& Rousseau, Tafelberg en J.L. van Schaik) en ander uitgewerye soos Perskor, Daan Retief en J.P. van der Walt \& Seun bestaan. Hierdie skeiding ondersteun 'n persepsie dat eersgenoemde uitgewerye "beter" boeke publiseer en laasgenoemde uitgewerye meer "populêre" boeke publiseer of gepubliseer het.

Uit die outeursprofiel blyk dit dat outeurs hoofsaaklik by een of hoogstens by twee uitgewerye publiseer. Voorbeelde van outeurs wat slegs by een uitgewery in dié tydperk publiseer, is Jan Combrink by J.P. van der Walt \& Seun, Tertia Botha by Tafelberg; Corlia Fourie by Human \& Rousseau; Louise van Niekerk (ook onder die pseudoniem Louis van Niekerk) by Perskor/Kagiso; Janie Oosthuysen by Human \& Rousseau; Carl Steyn en Prevot van der Merwe by J.P. van der Walt \& Seun; E.P. Victor by Perskor; en George Weideman by Tafelberg.

Indien outeurs by meer as een uitgewery publiseer, bly die outeurs oor die algemeen óf by die Nasboek-groep óf by laasgenoemde groep uitgewerye soos hierbo aangedui. Anne Hite Kemp publiseer

Vanaf 2004 word na Nasboek as Via-Afrika verwys. 
byvoorbeeld by Perskor en J.P. van der Walt \& Seun; Brenda Schröder en Nina van Vliet by Daan Retief/Kennis Onbeperk en J.P. van der Walt \& Seun; Rona Rupert, Rena Schüler, Marianna Brandt en Marita van der Vyver by Tafelberg en Human \& Rousseau; en De Waal Venter by Human \& Rousseau en Queillerie11. Dit lyk dus of daar 'n sekere lojaliteit tussen uitgewerye en outeurs bestaan.

Uitsonderings is Pieter W. Grobbelaar wat by Daan Retief, LAPA en Human \& Rousseau publiseer; Hesma Nel wat een titel by Tafelberg en vier by J.P. van der Walt \& Seun publiseer; Jonita Swart wat vier boeke by J.P. van der Walt \& Seun en een by Tafelberg publiseer; Nel Swart wat een boek by Tafelberg en twee boeke by J.P. van der Walt \& Seun onder die skuilnaam Jo Jooste uitgee, en Engela van Rooyen wat onderskeidelik twee boeke by Tafelberg en JutaLiterêr publiseer, maar as Engela Linde drie boeke by Daan Retief uitgee. Die feit dat die meeste van hierdie outeurs as uitsonderings genoem word en meer boeke by die "populêre" uitgewerye uitgee of onder skuilname by die "populêre" uitgewerye uitgee, versterk die persepsie van 'n tweedeling binne uitgewerye wat Afrikaanse kinder- en jeugprosa uitgee.

Daar is egter aan die einde van die periode 1990-2001 'n aanduiding van ten minste 'n gedeeltelike opheffing van die tweedeling. Martie Preller wat hoofsaaklik by die Nasboekgroep uitgee, gee vanaf 2000 ook by LAPA uit. Ook Heleen Roux wat aanvanklik by Tafelberg uitgee, publiseer vanaf 2001 by LAPA en Francois Bloemhof wat nege van sy tien boeke in die periode 1990-2001 by die Nasboek-groep uitgee, gee vanaf 2001 ook 'n titel by LAPA uit.

Franci Greyling en Maretha Maartens is uitsonderings op die reël soos hierbo aangedui, en het veroorsaak dat die invloed van kompetisies op outeurs se keuse van uitgewerye ondersoek word. Greyling publiseer vier boeke by Human \& Rousseau en Tafelberg, maar een boek by J.P. van der Walt \& Seun, naamlik Kransduif en Edelvalk (1991), waarvoor sy die Volkskasbank-prys vir jeuglektuur ontvang wat gevolglik by J.P. van der Walt \& Seun gepubliseer word. Maartens is die outeur wat by die meeste uitgewerye publiseer, onder andere Pro Biblia, Tafelberg, Perskor en HAUMLiterêr. Sy verower vir die twee boeke wat sy by Tafelberg publiseer, naamlik Plek van die dolfyne (1990) en Spinnekopsomer (1992), 'n Sanlam-prys. In 1989 wen Maartens egter ook die Volkskasbank-

11 Quellerie was ook 'n Nasboek-uitgewery. 
prys vir jeuglektuur en haar boek Op Filippa se planeet word by J.P.van der Walt \& Seun uitgegee. Dieselfde gebeur met Die baba luister (2002) wat pryswenners in die Baba-en-kleutertydskrifstoriekompetisie is en gevolglik deur LAPA uitgegee is. Dit lyk dus of die toekenning en beskikbaarheid van pryse wel 'n rol speel in die verhouding tussen uitgewerye en outeurs van Afrikaanse kinder- en jeugprosa, veral as in ag geneem word dat Greyling ook vir haar roman Dirkie Drieka Frederika in 1989 die Sanlam-prys (brons) ontvang.

\subsection{Die outeursprofiel en Afrikaanse kinder- en jeugboekpryse}

Uit die voorafgaande het dit geblyk dat die verhouding tussen die outeursprofiel, die uitgewersprofiel en die toekenning en/of verowering van pryse en toekennings belangrik is. Daar is gevolglik ondersoek ingestel na die verhouding tussen outeurs wat pryse wen en die uitgewerye waar hulle publiseer.

Pryse vir Afrikaanse kinder- en jeugprosa val hoofsaaklik in twee groepe uiteen:

- die pryse wat op grond van literêre kwaliteit deur volwasse beoordelaars toegeken word; en

- pryse wat op grond van gewildheid deur teikenlesers toegeken word.

Eersgenoemde groep sluit die volgende pryse in en sal vir die doeleindes van hierdie artikel prestigepryse genoem word:

- die Scheepers-prys vir jeugliteratuur, toegeken deur die SuidAfrikaanse Akademie vir Wetenskap en Kuns vir "werk wat van goeie letterkundige en/of opvoedkundige gehalte moet getuig" (die skenkingsakte, soos aangehaal in Wybenga \& Snyman, 2004);

- die C.P. Hoogenhout-toekenning vir die "beste oorspronklike Afrikaanse kinderboek" (Wybenga \& Snyman, 2004), tans toegeken deur die Eenheid vir Navorsing in Kinderliteratuur;

- die Tienie Holloway-medalje, toegeken deur die Suid-Afrikaanse Akademie vir Wetenskap en Kuns vir die outeur wat die "beste werk van bevredigende gehalte" gelewer het (Wybenga \& Snyman, 2004); 
- die Alba Bouwer-prys vir kinderliteratuur, toegeken deur die SuidAfrikaanse Akademie vir Wetenskap en Kuns vir "literêre werk in die kategorie kinderliteratuur (lesers van sewe tot twaalf)" (Wybenga \& Snyman, 2004);

- die Sanlam-pryse vir manuskripte van "gehalte" (Wybenga \& Snyman 2004), wat na die toekenning van die prys in sommige gevalle deur Tafelberg gepubliseer word;

- die M.E.R.-prys wat aan die "beste" (Wybenga \& Snyman, 2004) kinder- of jeugverhaal wat jaarliks by uitgewerye van Nasionale Pers verskyn, toegeken word; en

- die Volkskasbank-prys vir jeuglektuur wat tussen 1989 en 1993 toegeken is vir manuskripte wat gerig is op lesers van 11 tot 18 jaar oud en by J.P.van der Walt en Seun verskyn het (Wybenga \& Snyman, 2004).

Onder die prestigepryse val dus pryse wat slegs toegeken word vir titels wat by bepaalde uitgewerye verskyn, maar ook die onafhanklike pryse van die Suid-Afrikaanse Akademie vir Wetenskap en Kuns en die C.P. Hoogenhout-toekenning. Behalwe in die geval van die C.P. Hoogenhout-toekenning, waar die wenner slegs 'n medalje verower, is 'n kontantbedrag van wisselende waarde aan al die ander pryse gekoppel.

In die tweede kategorie is daar net een prys ter sprake, naamlik die ATKV-kinderboektoekenning wat vanaf 1991 bestaan. Uit al die oorspronklike Afrikaanse kinder- en jeugboektitels wat in een jaar by enige uitgewery verskyn, wys kinderlesers wenners in vyf ouderdomskategorieë vir hierdie toekenning aan. Geen voorafkeuring van boeke word gedoen en geen arbitrasie deur volwassenes vind plaas nie. Daar is ook tot en met 2002 geen kontantbedrag aan die prys gekoppel nie.

Wanneer gekyk word na die uitgeweryprofiel van outeurs aan wie toekennings gemaak is, kan verskillende afleidings gemaak word.

Pryse, veral pryse wat aan manuskripte toegeken word, is 'n geslaagde middel om outeurs en manuskripte te werf. Die geval van Maartens en Greyling bevestig dit. Hierdie aanname word ook ondersteun deur ander gevalle. Elsa Hamersma ontvang die Sanlamprys vir Die teken van crux (1997), die enigste titel van haar wat gepubliseer word, hoewel sy 'n tweede prys in 'n wedstryd van FNB/Kagiso-uitgewerye vir die ongepubliseerde Die hart van Hillbrow ontvang. Ook Jan Vermeulen se eerste (en tans enigste) 
jeugboek, Geraamtes dra nie klere nie (2000), is 'n Sanlam-pryswenner en wen ook daarna die Scheepers-prys.

Trouens, vyf titels uit 'n moontlike 15 titels (33,33\%), wat deur vier outeurs geskryf is en wat in die periode 1990-2001 'n Sanlamtoekenning ontvang, wen ook een of meer van die onafhanklike pryse. Die volgende Sanlam-pryswennerouteurs ontvang vir drie agtereenvolgende jare ook die Scheepers-prys: George Weideman met Optog van die aftjoppers (1994), Leon de Villiers met Die pro (1997) en Jan Vermeulen met Geraamtes dra nie klere nie (2000). Martie Preller ontvang vir Anderkantland (1994) en Barrie Hough vir Droomwa (1990) ook die C.P. Hoogenhout-toekenning, terwyl Hough vir dieselfde titel ook die Alba Bouwer-prys ontvang.

Dit lyk beslis asof die toekenning van pryse en veral pryse wat deur 'n kompetisie voorafgegaan word, outeurs aanmoedig om manuskripte te lewer en boeke by bepaalde uitgewerye uit te gee. Nie net hou die publisiteit en prestige wat met die toekenning van pryse gepaardgaan 'n bepaalde bemarkingswaarde vir uitgewerye en outeurs in nie, maar is die kontantbedrag (weliswaar beperk in sommige gevalle) waarskynlik ook 'n faktor wat outeurs aanmoedig om te skryf.

Wanneer die pryswennerstitels van die prestigepryse en die ATKVtoekennings vergelyk word, kan die volgende afleidings gemaak word:

- Met die uitsondering van Baker se Spore op die maan (1991) wat by HAUM-Literêr verskyn, word al 15 die titels wat in die tydperk 1990-2001 onafhanklike pryse ontvang, deur óf Tafelberg óf Human \& Rousseau uitgegee, terwyl hulle slegs $41 \%$ van die algehele produksie oorspronklike Afrikaanse kinder- en jeugprosa in die tydperk lewer.

- In Figuur 7 word die verspreiding van uitgewerye wat wenners van die ATKV-toekennings se boeke publiseer, aangetoon. Dieselfde groepering van uitgewerye word gebruik as vroeër in die artikel.

As in ag geneem word dat sowel Daan Retief/Kennis Onbeperk en Perskor/Kagiso in die tydperk 1990-2001 ophou publiseer, lyk die verspreiding van uitgewerye wat pryswennertitels vir die ATKVtoekennings publiseer meer verteenwoordigend as in die geval van die onafhanklike pryse. Tafelberg publiseer die meeste titels (26,5\%) wat ATKV-pryse verower, terwyl Human \& Rousseau en J.P. van der Walt en Seun elk 18,3\% van die titels uitgee. Gesamentlik 
publiseer uitgewerye van Nasboek by hierdie toekenning 48,9\% van die pryswenners.

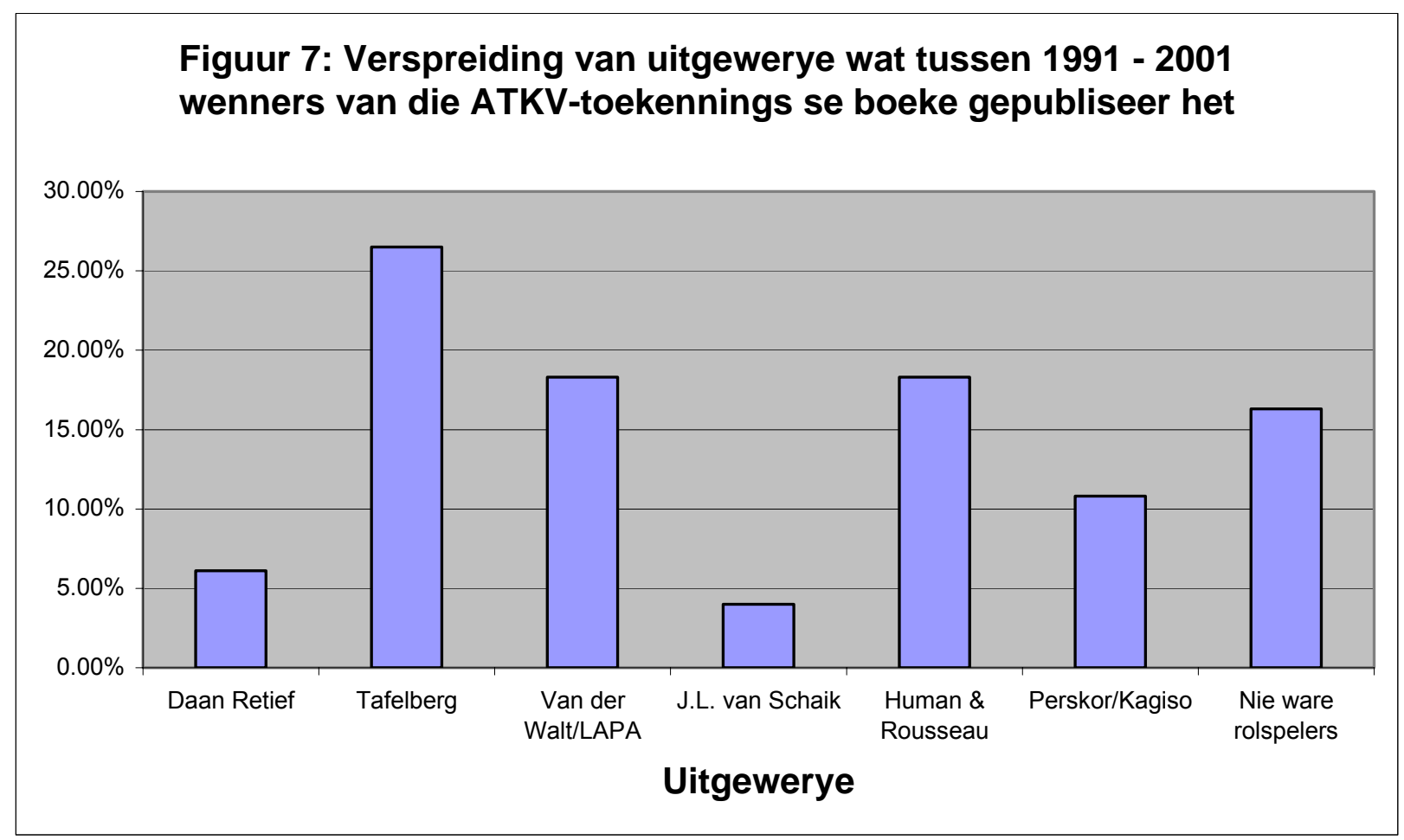

Uit 'n totaal van 59 outeurs wat by albei prysgroeperings betrokke is, is daar slegs vyf outeurs $(8,4 \%)$ wat sowel ATKV-toekennings as prestigetoekennings vir een of meer van hulle boeke ontvang. Hulle is Leon de Villiers, Barrie Hough, Martie Preller, Janie Oosthuysen en Jan Vermeulen.

Uit die 64 titels wat by die toekenning van pryse van Afrikaanse kinder- en jeugprosa vir die tydperk 1990-2001 ter sprake kom, is daar slegs vyf van die titels wat 'n prestigeprys wen en ook 'n ATKVtoekenning verower. Benewens Liewe Heksie en die rekenaar (1999) van Verna Vels, wat sowel 'n ATKV-toekenning as die C.P. Hoogenhout-toekenning en die Tienie Holloway-medalje verower, is dit slegs Droomwa (1990) en Vlerkdans (1992) van Barrie Hough en Martie Preller se Balkieboek (2000) wat sowel 'n ATKV-toekenning as die Alba Bouwer-prys wen; Jan Vermeulen se Geraamtes dra nie klere nie (2000), wat 'n ATKV-toekenning en die Scheepers-prys verower, en Tertia Botha se Rebel (1994) wat 'n ATKV-toekenning en die Sanlam-prys (brons) inpalm.

Drie uit die ses boeke wat Corlia Fourie in die periode 1990-2001 publiseer, verower vyf van die prestigepryse. Sy ontvang die Tienie 
Holloway-medalje vir Die meisie wat soos 'n bottervoël sing (1990) en vir Die towersak en ander stories (1994) en Die wit vlinder (1993) die Alba Bouwer-prys. Vir Die meisie wat soos 'n bottervoël sing en Die towersak en ander stories wen sy ook die M.E.R.-prys. Nie een boek van hierdie outeur ontvang egter 'n ATKV-toekenning nie.

Hierdie groot diskrepansie in die toekenning van die pryse dui nie slegs op die relatiwiteit van prystoekennings oor die algemeen nie, maar betrek ook die vraag wie die meriete van kinder- en jeugliteratuur moet bepaal, aangesien die aanwesigheid van 'n volwasse tussenganger die proses ipso facto meer ingewikkeld maak as by pryse vir volwasse prosa (Ghesquiere, 1991).

\section{Gevolgtrekking}

Die afleidings wat gemaak is op grond van die outeursprofiel van die produksiekategorie Afrikaanse kinder- en jeugprosa (fiksie) vir die tydperk 1990-2001, toon aan dat daar 'n verskuiwing plaasgevind het in die uitgeefilosofie van uitgewerye wat binne hierdie produksiekategorieë publiseer. Daar is klaarblyklik (veral in die laaste drie jaar van die periode) 'n poging om die behoeftes van die teikenleser beter te verstaan en te betrek. Dit blyk onder andere uit die uittrede van bestaande outeurs en die toetrede van jeugdige outeurs, uitgewers, keurders en resensente tot hierdie produksiekategorie. Hierdie verskuiwing is waarskynlik beïnvloed deur die ineenstorting van die voorskryfmark en die gevolglike noodsaak om die algemene mark te ontgin.

Die belangrike rol wat die uitgewer, maar ook ander rolspelers binne die produksiekategorie speel, word weereens beklemtoon. Dit lyk byvoorbeeld of veranderinge in die uitgeefilosofie nie net die gevolg was van finansiële druk wat veroorsaak is deur politieke veranderinge en die ineenstorting van die voorskryfmark nie, maar ook ten dele veroorsaak is deur die groter klem op 'n lesergesentreerde benadering deur navorsers en ander belanghebbendes wat in en oor die kinder- en jeugboekveld publiseer (Snyman, 1994; 2001; Fairer-Wessels \& Van der Walt, 1999; Van der Westhuizen, 1999; Verwey, 1999).

Dit lyk verder asof die toekenning van pryse, en veral pryse wat deur 'n kompetisie voorafgegaan word, outeurs aanmoedig om manuskripte te lewer en boeke by bepaalde uitgewerye uit te gee.

Daar is egter ook leemtes geïdentifiseer. 
Ten spyte van die groter klem op die behoeftes van die teikenleser, veroorsaak die afwyking tussen die toekennings van die prestigepryse en die ATKV-toekennings stof tot nadenke. Hoewel die toekenning van pryse vir kinder- en jeugboeke in die besonder problematies is, weerspreek die huidige situasie die toenadering van uitgewerye tot die algemene mark. Die negatiewe gevolge van die toekenning van pryse aan boeke waarvan kinders nie hou nie, is al ten opsigte van Afrikaanse kinder-en jeugliteratuur aangeteken (Snyman, 1992); so ook die negatiewe korrelasie tussen die boeke wat volwassenes aanprys en wat kinders as aanvaarbaar beleef (Ghesquiere, 1997:133). Van der Westhuizen (1999:130) verwys ook na die feit dat die teikenleser "verreken (moet) word in ... 'n beskouing van wat as norm vir goeie jeugliteratuur geld". Die benadering wat vanaf 2004 met die toekenning van die M.E.R.-prys gevolg is - waarin sowel kinders as volwasse beoordelaars betrek is - is moontlik 'n oplossing vir 'n probleem wat inherent kompleks is.

Ten spyte van die toetrede van jonger outeurs, is die aanbod van outeurs tot hierdie produksiekategorie steeds beperk en sal uitgewers 'n besliste poging moet aanwend om outeurs te werf en op te lei, om sodoende die produksievlak en verskeidenheid van die beskikbare Afrikaanse kinder- en jeugprosa te verhoog.

Dit ly ook geen twyfel nie dat uitgewers uit hulle pad sal moet gaan om outeurs uit die breër Afrikaanstalige gemeenskap vir die skryf van Afrikaanse kinder- en jeugprosa te wen. Die Afrikaanse taalgemeenskap kan dit nie langer bekostig dat so 'n groot groep feitlik glad nie in die Afrikaanse jeugboekbedryf verteenwoordig word nie.

Hierdie outeursprofiel kon en het wel bepaalde tendense en/of leemtes in die produksiekategorie Afrikaanse kinder- en jeugprosa (fiksie) uitgewys. Dit lyk tog of dit waarde inhou om statistiek, wat 'n oorkoepelende blik op 'n bepaalde produksiekategorie verskaf, te onderhou en te ontleed. Sulke statistiek bied 'n agtergrond waarteen uitgewers en ander rolspelers verskillende scenario's kan toets en oorweeg en grondige waarnemings kan maak, waarvolgens meer gefundeerde uitsprake gemaak kan word wat meer gewig sal kan dra.

\section{Geraadpleegde bronne}

BERG, B.L. 1998. Qualitative research for the social sciences. London: Allyn \& Bacon. 
BREYTENBACH, K. 1999. Is dit ons erns met Afrikaanse jeugboeke? Boekewêreld, Bylae by Nasionale Koerante: 6, Jul. 28.

FAIRER-WESSELS, F. \& VAN DER WALT, T. 1999. Temas en tendense in hedendaagse kinderliteratuur. Stilet, 11(1):95-106.

GALLOWAY, F. 2002. Statistical trends in South African book publishing during the 1990s. Alternation, 9(1):204-225.

GHESQUIERE, R. 1997. Het verschijnsel jeugdliteratuur. 6e druk. Leuven: Acco.

JACOBS, J. 2002. Droogte aan tienerromans gebreek. Volksblad: 8, Nov. 25.

NIEUWOUDT, S. 2001. Flieks en roomys: Parker se navorsing. Beeld: 8, April 28.

SAMUELS, S. 2004. Waar is eie kinderboeke? Jip (Bylaag tot Beeld): 2, Mei 3.

SMITH, F. 2004. 'n Passie vir boeke. Plus (Bylaag tot Beeld): 9, Mei 25.

SNYMAN, M. 1999. Hoekom en hoe ek vir jong mense skryf. Stilet, 11(1):107114.

SNYMAN, M. 2001. Die plek van die jeugreeksboek in die geskiedenis van die Afrikaanse letterkunde. Tydskrif vir Letterkunde, 39(1/2):46-59.

SNYMAN, M. \& VENTER, R. MR. 2004. Produksiepatrone van Afrikaanse kinder- en jeugprosa: 'n verkennende statistiese ontleding 1990-2001. Musaion, 22(1): bladsye nog nie beskikbaar nie.

SNYMAN, M.E. 1994. Die Afrikaanse jeugliteratuur: 'n herbesinning. Tydskrif vir Letterkunde, 32(3):39-53.

VAN DER WESTHUIZEN, B. 1999. 'n Polisistemiese benadering tot die bevordering van kleuter-, kinder- en jeugliteratuur. Stilet, 11(1):125-140.

VENTER, R. MR. 2004. 'n Empiriese ondersoek na die produksie van Afrikaanse fiksie gedurende die periode 1990-2003 - met toespitsing op die produksieprofiel, uitgeweryprofiel en uitgeesisteem (Voorlopige titel). Pretoria: Universiteit van Pretoria. (Onvoltooide en ongepubliseerde M.ISverhandeling.)

VENTER, R. MR. \& GALLOWAY, F. 2002. Die uitgeesisteem van Afrikaanse fiksie gedurende die periode 1990-2001. 'n Voorlopige verkenning van die verhouding tussen produksieprofiel, redaksionele beleid en markverskuiwing, -verruiming of -inkrimping. Ongepubliseerde referaat, Afrikaanse Letterkundevereniging (ALV)-kongres, 30 September - 3 Oktober 2002, Dikhololo Natuurreservaat.

VERWEY, H. 1999. Die jong lesers van Centurion: Wat lees hulle en waarom? Stilet, 11(1):115-120.

WYBENGA, G. \& SNYMAN, M., reds. 2004. Van Patrys-hulle tot Hanna Hoekom. 'n Gids tot die Afrikaanse kinder- en jeugboek. Pretoria: LAPA.

\section{Kernbegrippe:}

Afrikaanse kinder- en jeuglektuur

outeursprofiel

publikasietendense

\section{Key concepts:}

Afrikaans children's and youth literature

author's profile

publication trends 